\title{
Assessment of serum enzymatic markers of cardiomyocytes injury in female dogs submitted to ketamine $S(+)$, atropin and xylazine association ${ }^{1}$
}

\author{
Mensuração da atividade sérica de marcadores de lesão cardíaca em cadelas anestesiadas com \\ cetamina $\mathrm{S}(+)$, atropina e xilazina
}

\author{
Leandro Guimarães Franco ${ }^{\mathrm{I}}$, Maria Clorinda Soares Fioravanti" ${ }^{\mathrm{II}}$, Adilson Donizeti Damasceno ${ }^{\mathrm{II}}$, Aline Cardoso Borges ${ }^{\mathrm{III}}$, Lorena \\ Karine Soares $^{\text {IV }}$, Rogério Elias Rabelov ${ }^{\mathrm{V}}$, Luiz Antônio Franco da Silva ${ }^{\mathrm{VI}}$ \\ I DVM, Fellow PhD degree, Post Graduation Program in Animal Science, Veterinary College, UFG, Goias, Brazil. \\ ${ }^{\text {II }}$ DVM, PhD, Associated Professor, Department of Veterinary Medicine, Veterinary College, UFG, Goias, Brazil. \\ III DVM, Master, Animal Inspection Service, Ministery of Agriculture, Goias, Brazil. \\ IV Graduate Student, Veterinary College, UFG, Goias, Brazil. \\ ${ }^{v}$ DVM, Master, Assistant Professor, Campus of Jataí, UFG, Goias, Brazil. \\ ${ }^{\text {VI }}$ DVM, PhD, Associated Professor and Head, Department of Veterinary Medicine, Veterinary College, UFG, Goias, Brazil.
}

\begin{abstract}
Purpose: To assessment of the aspartate aminotransferase (AST), creatine kinase (CK) and creatine kinase isoenzyme fraction MB (CK-MB) serum activity in female dogs anesthetized with ketamine $\mathrm{S}(+)$, atropine and xylazine in several associations. Methods: Twenty three healthy female dogs randomly distributed in four groups named as GI ( $n=6)$, GII (n=6), GIII ( $n=6)$ and GIV $(\mathrm{n}=5)$ were treated respectively with atropine and ketamine $\mathrm{S}(+)(0.04 \mathrm{mg} / \mathrm{kg} ; 10 \mathrm{mg} / \mathrm{kg}) ;$ ketamine $\mathrm{S}(+)(10 \mathrm{mg} / \mathrm{kg}) ;$ atropine, $\mathrm{xylazine}$ and ketamine $\mathrm{S}(+)(0.04 \mathrm{mg} / \mathrm{kg} ; 1.1 \mathrm{mg} / \mathrm{kg} ; 10 \mathrm{mg} / \mathrm{kg})$ and xylazine and ketamine $\mathrm{S}(+)(1.1 \mathrm{mg} / \mathrm{kg} ; 10 \mathrm{mg} / \mathrm{kg}) . \mathrm{AST}, \mathrm{CK}$ and CK-MB serum activity measurement before pre-medication (M0) and one, two, three, six, 12, 24, 36 hours after. Results: There was no significant change in AST, CK e CK-MB serum activity among groups. However, CK serum activity in relation to moments within the groups was increased in all groups over the time in spite of treatment, except GI.In relation to CK-MB activity, in the moments within the group, it was observed an increase compared to baseline in all groups. Conclusion: Creatine kinase and creatine kinase fraction MB isoenzyme showed changes in their mean values remained higher than baseline for a longer time in GIII and GIV.
\end{abstract}

Key words: Isoenzymes. Atropine. Xylazine. Heart. Ischemia. Anesthetics, Dissociative. Dogs.

\section{RESUMO}

Objetivo: Determinar a atividade sérica de AST, CK e CK-MB em cadelas anestesiadas com cetamina S (+), atropina e xilazina em diferentes associações. Métodos: Vinte e três cadelas saudáveis foram distribuídas ao acaso em quarto grupos denominados GI (n=6), GII $(n=6)$, GIII $(n=6)$ e GIV $(n=5)$ tratados respectivamente com atropina e cetamina $\mathrm{S}(+)(0,04 \mathrm{mg} / \mathrm{kg} ; 10 \mathrm{mg} / \mathrm{kg}) ; \mathrm{cetamina} \mathrm{S}(+)$ $(10 \mathrm{mg} / \mathrm{kg})$; atropina, xilazina e cetamina $\mathrm{S}(+)(0,04 \mathrm{mg} / \mathrm{kg} ; 1,1 \mathrm{mg} / \mathrm{kg} ; 10 \mathrm{mg} / \mathrm{kg})$ exilazina e cetamina $\mathrm{S}(+)(1,1 \mathrm{mg} / \mathrm{kg} ; 10 \mathrm{mg} / \mathrm{kg})$. A atividade sérica de AST, CK e CK-MB foi determinada antes da pré-medicação (M0) e uma, duas, três seis, 12,24 e 36 horas após M0. Resultados: Não foram encontradas mudanças significativas na atividade sérica de AST, CK e CK-MB entre grupos. Entretanto, entre momentos houve aumento da atividade sérica de CK para todos os grupos, exceto em GI.Com relação a atividade sérica de CK-MB, observou-se ao longo dos momentos aumento significativo com relação aos valores basais em ambos os grupos. Conclusão: Alterações significativas foram observadas com relação à atividade sérica de CK e CK-MB em todos os tratamentos, mantendo-se elevada por um período maior nos grupos GIII e GIV.

Descritores: Isoenzima. Atropina. Xilazina. Coração. Isquemia. Anestésicos Dissociativos. Cães.

${ }^{1}$ Research performed at Animal Science Post-Graduation Program, Veterinary College, Federal University of Goias (UFG), Brazil.

\section{Introduction}

The cardiovascular system is constantly exposed to the risk of injuries caused by drugs, such as myocardium lesions secondary to transitory ischemia. ${ }^{1}$ Anesthetic drugs such as ketamine, the main type of dissociative group, are considered to be potentiallyharmful to the cardiovascular system. ${ }^{1,2}$
Ketamine, a phencyclidine derivative, is commercially available in racemic form or as an $\mathrm{S}(+)$ purified isomer. The racemic form consists of a mixture of $\mathrm{S}(+)$ and $\mathrm{R}(-)$ isomers. ${ }^{3}$ Ketamine activates the sympathetic system resulting in an increaseinheartrate and output and oxygen consumption by the 
myocardium. However, a high in vitro concentration of ketamine resulted in a decrease in the contractility of canine myocardium culture cells. ${ }^{4,5}$

Due to these important side effects, ketamine has been used in combination with tranquilizers or sedatives, such as xylazine. ${ }^{6}$ The xylazine-ketamine association is one of the most widely used anesthetic techniques in veterinary practice. ${ }^{7,8}$ Although, xylazine counter-balances the undesirable effects of ketamine, its use can cause cardiovascular abnormalities arising from a decrease in sympathetic tonus. ${ }^{9}{ }^{10}$ A microscopic study of the heart of rabbits anesthetized with xylazine-ketamine showed cellular degeneration and fibrosis, which are commonly observed after tissue hipoperfusion resulting from the coronary constriction that occurs immediately after xylazine administration. ${ }^{11}$ Moreover, $\mathrm{Xu}$ et al. ${ }^{12}$ described depression and hemodynamic instability in rats which underwent anesthesia with xylazine-ketamine.

In order to reduce the undesired effects of xylazine, the addition of atropine sulphate in the xylazine-ketamine protocol has been widely reported. ${ }^{13,14}$ However, atropine associated with xylazine-ketamine can increase the heart rate with a consequent rise in cardiac work and oxygen consumption and a reduction in ventricular ejection fraction and coronary perfusion. ${ }^{13,15}$ LindeSipman et $a l .{ }^{16}$ reported myocardium degeneration and necrosis secondary to ischemia in cats which died after administration of ketamine in different associations with atropine and xylazine.

In order to detect myocardium injuries, noninvasive assessment of specific cardiac markers has been used clinically and experimentally in the last few years. ${ }^{17}$ The biochemical markers aspartate aminotransferase (AST), creatine kinase (CK) and creatine kinase isoenzyme fraction $\mathrm{MB}$ (CK-MB) have been used for the detection of heart damage. ${ }^{18}$ Although AST is a non-specific heart lesion, increase in its serum activity is detected when there is severe myocardium damage. ${ }^{19}$ Moreover, AST serum measurement is frequently associated with $\mathrm{CK}$ dosage, a more specific marker to complement changes observed in $\mathrm{CK}$ serum activity. ${ }^{20} \mathrm{CK}$ is a dimeric enzyme consisting of two subunits, $\mathrm{M}$ (muscle type) and $\mathrm{B}$ (brain type), resulting in three different isoenzymes: $\mathrm{MM}, \mathrm{BB}$ and $\mathrm{MB} \cdot{ }^{18}$

The activity of $\mathrm{CK}$ isoenzyme MB (CK-MB), a CK isoenzyme specific to myocardium, increases a few hours after cell damage, reaches maximum levels in 12 hours and goes back to baseline within 24 to 48 hours. ${ }^{21}$ In the last few years, clinical application of CK-MB assessment in dogs has been reported, mainly related to previous cardiac diseases and trauma. ${ }^{22,23}$ However, this response is different in comparison to others species, since dogs have developed a collateral myocardium irrigation system. This parallel circulation system acts in response to coronary inflow decrease and leads to underestimationof the alteration of cardiac rhythm and serum enzyme activity, especially related to $\mathrm{CK} .{ }^{24}$ Even so, Mehta et al. ${ }^{25}$ reported that in the myocardium cells of dogs, short-duration anoxia induced a decrease in M-mRNA and an increase in the concentration of B-mRNA, resulting in a $35-100 \%$ elevation of CK-MB activity depending on duration of the ischemia.Experimental induction of myocardial ischemia in dogs has shown that partial or total occlusion of coronary branches significantly raises CK-MB serum activity. ${ }^{26}$

Despite myocardium collateral circulation, several studies have reported cardiac alterations in dogs secondary to administration of anesthetic drugs. ${ }^{27,28}$ Thus, it is reasonable to consider the existence of biochemical alterations resulting from the usage of ketamine $\mathrm{S}(+)$ and its associations. Moreover, experimental assays of cardiovascular effects and evaluation of enzymatic activity involving ketamine $\mathrm{S}(+)$ and its combinations in dogs are uncommon.

For these reasons shown, the purpose of the present study was to assess the serum activity of biochemical markers AST, CK and $\mathrm{CK}-\mathrm{MB}$ in dogs anesthetized with ketamine $(\mathrm{S}+)$, atropine and xylazine in several associations.

\section{Methods}

The experimental protocol was approved by the in Animal Research Ethics Committee of the Federal University of Goias ( $n^{\circ}$ 092/2006) and conducted in accordance with Brazilian College of Animal Experimentation norms.

Twenty-three mixed-breed, adult, female dogs, with a mean weight of $8.84 \pm 2.18 \mathrm{~kg}$ were randomly distributed in four groups: GI $(n=6)$, GII $(n=6)$, GIII $(n=6)$ and GIV $(n=5)$. The animals were considered healthy on the basis of a physical examination, cell blood count, biochemistry profile (creatinine, blood urea nitrogen, alanine aminotransferase, aspartate aminotransferase, alkaline phosphatase, creatine kinase, potassium, total protein and albumin), and ultrasonographic and electrocardiographic examinations. During the course of the study, they were fed a standard commercial diet, twice a day.

Prior to the experimental period, food was withheld for 10 and water for 2 hours. The left cephalic vein was punctured with a 22-ga catheter for drugs administration according to the protocol. All dogs received intravenous route (IV) physiologic saline solution until recovery from anesthesia. After anesthetic induction, the animals were positioned and kept in right lateral recumbency.

Group I dogs were given $0.04 \mathrm{mg} / \mathrm{kg}$ of atropine sulphate by the subcutaneous route (SC). Fifteen minutes after, the animals were anesthetized by the IV route with $10 \mathrm{mg} / \mathrm{kg}$ of ketamine $\mathrm{S}(+)$. GII animals received physiologic saline solution in equivalent volume of $0.04 \mathrm{mg} / \mathrm{kg}$ of atropine sulphate for each animal. After 15 minutes, animals were anesthetized with $1.1 \mathrm{mg} / \mathrm{kg}$ of xylazine followed by $10 \mathrm{mg} / \mathrm{kg}$ of ketamine $\mathrm{S}(+)$, both by the IV route. In GIII dogs, $0.04 \mathrm{mg} / \mathrm{kg}$ of atropine sulphate was given 15 minutes before $1.1 \mathrm{mg} / \mathrm{kg}$ of xylazine followed by $10 \mathrm{mg} / \mathrm{kg}$ of ketamine $\mathrm{S}(+)$,IV route. In GIV animals were given physiologic saline solution, by the SC route, and fifteen minutes later, $1.1 \mathrm{mg} / \mathrm{kg}$ of xylazine followed by $10 \mathrm{mg} / \mathrm{kg}$ of ketamine $\mathrm{S}(+)$, IV route. All groups were given $5.0 \mathrm{mg} / \mathrm{kg}$ of ketamine $\mathrm{S}(+)$, IV route, 10 minutes after the first administration. Animals were observed until they had complete recoveredfrom anesthesia.

Blood samples were collected from the jugular vein for AST, CK and CK-MB serum activity assessment before the administration of atropine sulphate or saline solution (M0) and one (M1h), two (M2h), three (M3h), six (M6h), twelve (M12h), twenty-four (M24h) and thirty-six (M36h) hours after M0. The baseline value for M0 wasthe average of the results of samples collected 48 hours, 24 hours and immediately before administration of atropine sulphate or saline solution.

Serum activity of enzymes was measured (UI/L) with a biochemical analyzer calibrated for a wave length of $340 \mathrm{~nm}$ at $37^{\circ} \mathrm{C}$ using commercial reagents. AST activity was determined 
by the fixed-time method. CK serum activity was measured by the kinetic method and CK-MB activity was assessed by the CK-M immunoinhibition method followed by serum activity measurement of CK-B by the kinetic method. The result obtained for CK-MB was divided by five as recommended for the method used.

Comparison among groups and among moments versus baseline in each group was performed with Kruskal-Wallis test. All values were expressed as mean \pm standard deviation.

Differences were considered significant at $\mathrm{p}<0.05$.

\section{Results}

There was no significant change in AST serum activity among groups atany moment. In relation to moments within the groups, a significant decrease in AST activity at M24h was observed in comparison to baseline in GI (Figure 1 and Table 1).

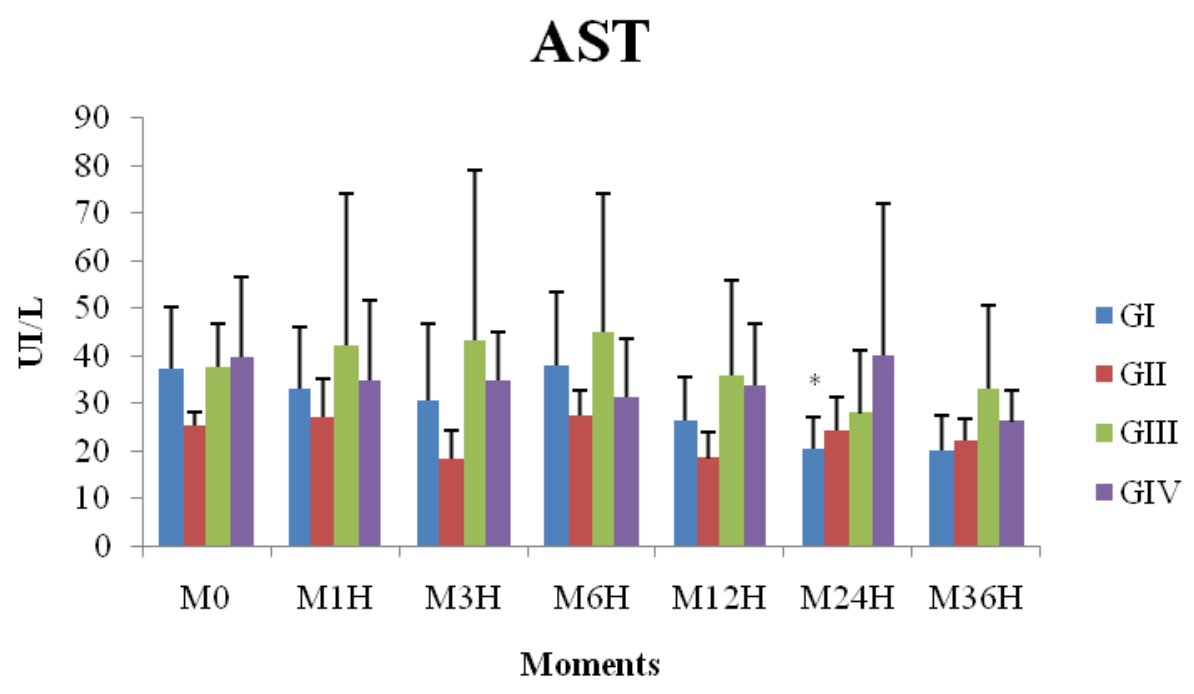

FIGURE 1 - Serum activity of aspartate aminotransferase (AST) in animalssubmitted to ketamine $\mathrm{S}(+)$, atropin and xylazine association during 36 hours

The columns represent the mean and vertical bars indicate the standard deviation. group GI ( $\mathrm{n}=6)$ : anesthesia with atropine and ketamine $\mathrm{S}(+),(0.04 \mathrm{mg} / \mathrm{kg} ; 10 \mathrm{mg} / \mathrm{kg})$; group GII ( $\mathrm{n}=6)$ : anesthesia with ketamine $\mathrm{S}(+)(10 \mathrm{mg} / \mathrm{kg})$;

group GIII (n=6): anesthesia with atropine, xylazine and ketamine $\mathrm{S}(+)(0.04 \mathrm{mg} / \mathrm{kg} ; 1.1 \mathrm{mg} / \mathrm{kg} ; 10 \mathrm{mg} / \mathrm{kg})$; group GIV $(\mathrm{n}=5)$ : anesthesia with xylazine and ketamine $\mathrm{S}(+)(1.1 \mathrm{mg} / \mathrm{kg} ; 10 \mathrm{mg} / \mathrm{kg})$.

$* \mathrm{P}<0.05$ comparated with baseline (M0).

TABLE 1 - Aspartate aminotransferase (AST) serum activity in animals submitted to ketamine $\mathrm{S}(+)$, atropin and xylazine association $\dagger$

\begin{tabular}{cccccccc}
\hline G & M0 & M1h & M3h & M6h & M12h & M24h & M36h \\
\hline I & $37,4 \pm 12,7$ & $33 \pm 13,2$ & $30,6 \pm 16,3$ & $38 \pm 15,4$ & $26,3 \pm 9,1$ & $20,3 \pm 6,6^{*}$ & $20,2 \pm 7,4$ \\
II & $25,4 \pm 2,8$ & $27,1 \pm 7,9$ & $18,3 \pm 6$ & $27,3 \pm 5,3$ & $18,5 \pm 5,4$ & $24,4 \pm 6,8$ & $22,1 \pm 4,5$ \\
III & $37,5 \pm 9,1$ & $42,1 \pm 31,8$ & $43,1 \pm 35,8$ & $45 \pm 29$ & $36 \pm 20$ & $28 \pm 13,3$ & $33 \pm 17,4$ \\
IV & $39,6 \pm 16,8$ & $34,8 \pm 16,8$ & $34,8 \pm 10,1$ & $31,2 \pm 12,3$ & $33,8 \pm 12,9$ & $40 \pm 32,1$ & $26,2 \pm 6,6$ \\
\hline
\end{tabular}

$\dagger$ The values appear as means \pm standard deviation. The index letters represent statistically significant differences between groups $(\mathrm{p}<0.05)$. * Statistical differences from baseline $(\mathrm{p}<0.05)$. 
CK activity showed a significant difference between GI and GII at M36h. The mean values in all groups increased over time in spite of treatment, except for GI, which showed a decrease from M12h and a mean that was lower at M36h than at baseline.
An increase at all moments was observed in relation to baseline value. This increase was more relevant in GII and GIII from M1h on, except at M24h in GIII (Figure 2 and Table 2).

\section{CK}

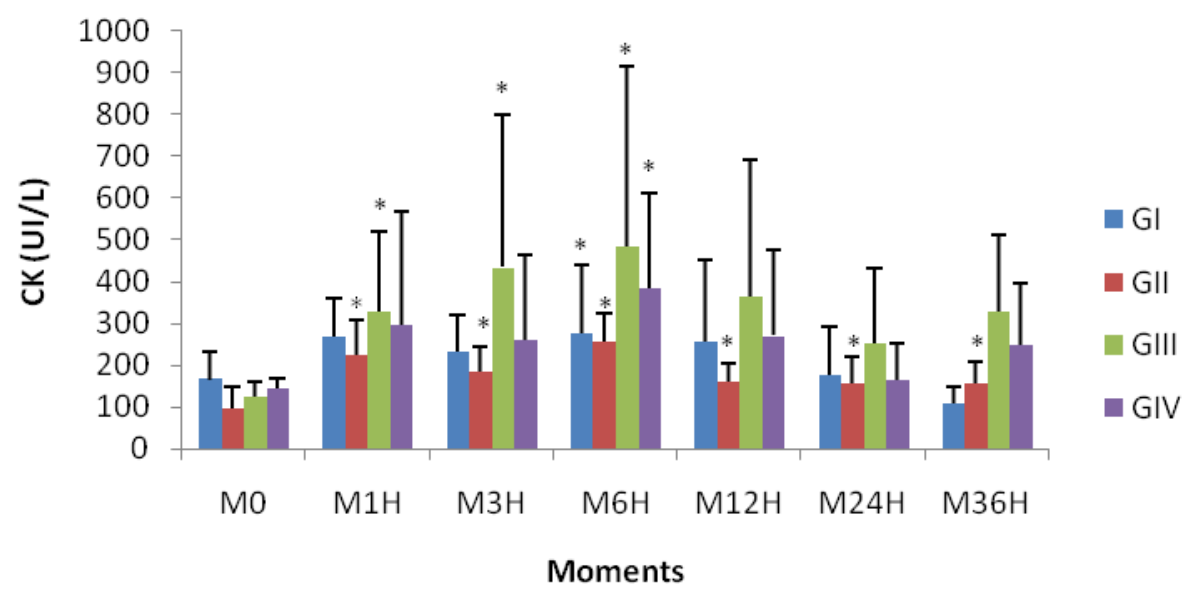

FIGURE 2 - Serum activity of creatine kinase (CK) in animalssubmitted to ketamine S(+), atropin and xylazine association during 36 hours

The columns represent the mean and vertical bars indicate the standard deviation. group GI (n=6): anesthesia with atropine and ketamine $\mathrm{S}(+),(0.04 \mathrm{mg} / \mathrm{kg} ; 10 \mathrm{mg} / \mathrm{kg})$; group GII ( $\mathrm{n}=6)$ : anesthesia with ketamine $\mathrm{S}(+)(10 \mathrm{mg} / \mathrm{kg})$;

group GIII (n=6): anesthesia with atropine, xylazine and ketamine $\mathrm{S}(+)(0.04 \mathrm{mg} / \mathrm{kg} ; 1.1 \mathrm{mg} / \mathrm{kg} ; 10 \mathrm{mg} / \mathrm{kg})$; group GIV ( $\mathrm{n}=5)$ : anesthesia with xylazine and ketamine $\mathrm{S}(+)(1.1 \mathrm{mg} / \mathrm{kg} ; 10 \mathrm{mg} / \mathrm{kg})$.

$* \mathrm{P}<0.05$ comparated with baseline (M0).

TABLE 2 - Creatine kinase (CK) serum activity in animalssubmitted to ketamine $\mathrm{S}(+)$, atropin and xylazine association $\uparrow$

\begin{tabular}{cccccccc}
\hline G & M0 & M1h & M3h & M6h & M12h & M24h & M36h \\
\hline I & $166 \pm 64$ & $266 \pm 92,5$ & $232,8 \pm 87,6$ & $274,8 \pm 166,4^{*}$ & $257,3 \pm 194,4$ & $177 \pm 114,7$ & $109 \pm 40,8^{\text {abd }}$ \\
II & $94,7 \pm 52,2$ & $225 \pm 80,9^{*}$ & $185,1 \pm 57,5^{*}$ & $254,6 \pm 70,1^{*}$ & $158,8 \pm 45,1^{*}$ & $155,0 \pm 63,4^{*}$ & $157,3 \pm 52,4^{\text {abcd* }}$ \\
III & $124,1 \pm 34,3$ & $328,3 \pm 191,1^{*}$ & $433,8 \pm 365^{*}$ & $482,8 \pm 430,8^{*}$ & $365,6^{*} \pm 326,9$ & $252,8 \pm 179,5$ & $326,2 \pm 184^{\text {bcd }} *$ \\
IV & $144 \pm 24,1$ & $295,8 \pm 273,2$ & $260,2 \pm 202,6$ & $382,2 \pm 230,1^{*}$ & $270 \pm 205,1$ & $164,8 \pm 86,6$ & $249,2 \pm 145^{\text {abcd }}$ \\
\hline
\end{tabular}

$\dagger$ The values appear as means \pm standard deviation. The index letters represent statistically significant differences between groups $(\mathrm{p}<0.05) . *$ Statistical differences from baseline $(\mathrm{p}<0.05)$.

There were no significant differences in CK-MB serum activity among the groups over time. Mean values showed high variability. At moments within the groups, an increase compared to baseline was observed in all groups treated with atropine sulphate. In GI, there was a significant difference from M3h until $\mathrm{M} 12 \mathrm{~h}$. In GIII, the difference was the increase of serum activity from M1h until M6h (Figure 3 and Table 3). 


\section{CK-MB}

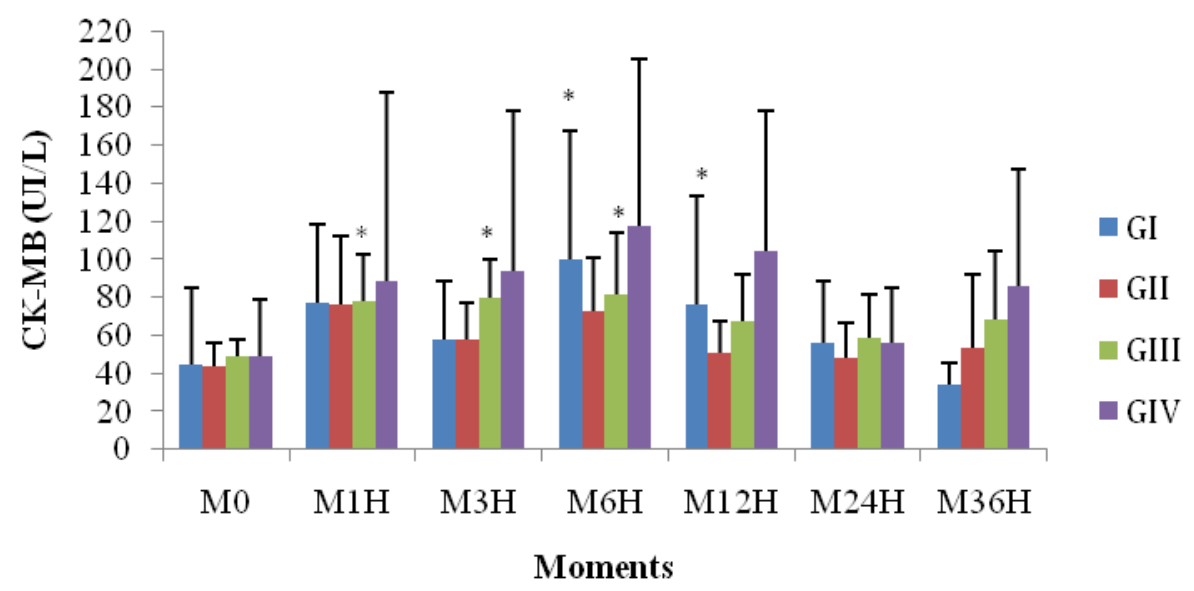

FIGURE 3 - Creatine kinase-MB (CK-MB) serum activity in animalssubmitted to ketamine S (+), atropin and xylazine association during 36 hours

The columns represent the mean and vertical bars indicate the standard deviation. group GI $(\mathrm{n}=6)$ : anesthesia with atropine and ketamine $\mathrm{S}(+),(0.04 \mathrm{mg} / \mathrm{kg} ; 10 \mathrm{mg} / \mathrm{kg})$; group GII $(\mathrm{n}=6)$ : anesthesia with ketamine $\mathrm{S}(+)(10 \mathrm{mg} / \mathrm{kg})$; group GIII (n=6): anesthesia with atropine, xylazine and ketamine $\mathrm{S}(+)(0.04 \mathrm{mg} / \mathrm{kg} ; 1.1 \mathrm{mg} / \mathrm{kg} ; 10 \mathrm{mg} / \mathrm{kg})$; group GIV ( $\mathrm{n}=5)$ : anesthesia with xylazine and ketamine $\mathrm{S}(+)(1.1 \mathrm{mg} / \mathrm{kg} ; 10 \mathrm{mg} / \mathrm{kg})$. $* \mathrm{P}<0.05$ comparated with baseline (M0).

TABLE 3 - Creatine kinase-MB (CK-MB) serum activity in animalssubmitted to ketamine $\mathrm{S}(+)$, atropin and xylazine association $\dagger$

\begin{tabular}{cccccccc}
\hline G & M0 & M1H & M3H & M6H & M12H & M24H & M36H \\
\hline I & $44,3 \pm 40,7$ & $76,9 \pm 41,8$ & $57,7 \pm 31$ & $99,8 \pm 67,8^{*}$ & $75,9 \pm 57,2^{*}$ & $56,4 \pm 31,8$ & $33,9 \pm 11,6$ \\
II & $43,8 \pm 12,0$ & $76 \pm 36,7$ & $57,5 \pm 19,2$ & $72,9 \pm 27,7$ & $50,7 \pm 16,8$ & $48,6 \pm 17,8$ & $53,9 \pm 37,9$ \\
III & $48,7 \pm 8,8$ & $77,9 \pm 24,3^{*}$ & $79,6 \pm 20,5^{*}$ & $81,6 \pm 32,2^{*}$ & $67,7 \pm 24,4$ & $59 \pm 22,4$ & $68,7 \pm 35,4$ \\
IV & $49,2 \pm 29,4$ & $88,6 \pm 98,8$ & $93,7 \pm 84,2$ & $117,7 \pm 87,4$ & $104,1 \pm 73,9$ & $55,7 \pm 29,1$ & $86,3 \pm 60,9$ \\
\hline
\end{tabular}

$\dagger$ The values appear as means \pm standard deviation. The index letters represent statistically significant differences between groups $(\mathrm{p}<0.05)$. *Statistical differences from baseline $(\mathrm{p}<0.05)$.

\section{Discussion}

The anesthetic protocols for ketamine $\mathrm{S}(+)$ proposed for this study were based on associations, doses and routes commonly used in the veterinary routine and widely described in the racemic ketamine literature. However, there have been few reports concerning biochemical marker assessment as a diagnostic tool for cardiac lesions associated with anesthetic drugs, as corroborated by Lopes et al. ${ }^{21}$ and Diniz et al. ${ }^{23}$. Moreover, these authors reported that use of biochemical markers has been restricted to experimental assays, mainly in dogs. Thus, the clinical application of specific markers for muscle damage can provide more information about the site and extension of tissue injury, according to Aktas et al. ${ }^{18}$

In this study, the increase in CK and CK-MB serum activity after drugs application imply that anesthetic protocols induced alterations in skeletal and cardiac muscle. However, such alterations were considered transient, since the mean values of enzymatic activity showed a decrease over the moments of evaluation. Furthermore, no changes in AST were found that could indicate more lasting and severe lesions, as Kramer and Hoffmann ${ }^{20}$ and Tadich et al. ${ }^{29}$ have also observed.

There were no statistical differences in CK serum activity among the treatments in any of the groups. However, compared to the reference value of this study, the mean values increased. These increases probably increases occurred as consequence of of a rise in MB-fraction related to muscular alterations due to the administration of ketamine $\mathrm{S}(+)$ associated with atropine in GI and GIII or xylazine effects in other groups. It is thus probably that the drugs caused muscle alterations explained by two hypotheses: an 
increase in cell metabolism secondary to the shrinking excess muscle and a decrease in oxygen supply to muscle.

The first hypothesis could be linked to ketamine $\mathrm{S}(+)$ action possibly associated with atropine. Ketamine can increase muscle work unleashing abrupt shrinking with higher hypertonicity. This is probably related to drug induced activation of cholinergic receptors. Thus, muscle alterations could explain the change in CK serum activity in these groups as described by Hjelms et al. ${ }^{30}$ and Aktas et al. ${ }^{18}$

Second hypothesis would be supported by the action of xylazine on tissue oxygen supply once Kolata and Rawlings ${ }^{6}$ and Marini et al. ${ }^{11}$ have described that xylazine even if combined with ketamine would induce transitory hypercapnia and tissue hypoxia. Thus, such events could be sufficient to promote alterations in CK serum activity as observed here.

The mean values of CK-MB serum activity obtained in this study increased more than baseline in all groups over the moments, although restricted use of this marker in dogs has been reported by Diniz et al. ${ }^{23}$. This is based on the rare occurrence of cardiac ischemic in dogs that would induce an increase in CK-MB serum activity. ${ }^{22}$ Another detail is related to the percentage of CK-MB isoenzyme distribution in dogs serum in baseline found in this study (35.17\% of total CK activity). This differs from results reported by Graeber et al. ${ }^{31}$ and Yasuda and Too $^{32}$ who obtained $18.2 \%$ and $16.1 \%$, respectively. However, our results were similar to those described by Lopes et al. ${ }^{21}$, who used the same CK-MB assessment protocol as we did.

Besides the changes in CK-MB serum activity, significant treatment effects were noted in all groups over time. However, an increase of mean values starting at M1h was observed in all groups, irrespective of the treatment. This result could indicate that anesthetic procedures were able to induce cardiomyocytes alterations. These findings were considered transitory in relation to total $\mathrm{CK}$, due to the fact that the mean values predisposed to normality over the time of evaluation. Although, the oxygen consumption and supply were not calculated, ketamine and xylazine could cause a decrease in the myocardium oxygen supply, which would be enough to induce increase in CK-MB serum activity in dogs according to Metha et al. ${ }^{25}$. This may be explained by the decrease in myocardium oxygen supply, whichinduces a fast decrease in M-subunit mRNA synthesis and an increase in the expression of B-subunit mRNA. ${ }^{25}$

Otherwise, whatever the protocol, the drugs could have promoted an increase in heart work and consequently an increase in myocardium oxygen consumption as reported by Linde-Sipman et al. ${ }^{16}$. Thus, this event could result in an increase in CK-MB serum activity as observed in the GI and GII dogs. However, according to the same authors, to establish ischemia there must be respiratory and hemodynamic abnormalities during the anesthetic procedure and this would compromise oxygen supply to cardiac muscle and would increase subsequent CK-MB serum activity. Unfortunately, the testsmentioned above were beyond the scope of this study.

Changes in CK-MB serum activity observed in the group treated with atropine, xylazine and ketamine $\mathrm{S}(+)$ were higher than baseline values for six hours after M0. This behavior could be related to the harmful effect of a combination of anesthetic on the myocardium as reported by Linde-Sipman et al. ${ }^{16}$ and Marini et al. ${ }^{11}$. Parsons et al. ${ }^{15}$ reported that an increase in stroke volume and cardiac output are essential for an increase in heart rate associated with afterload rising. Thus, as discussed above the limited number of variables considered in this study did not allow us to determine or observe such occurrences.

\section{Conclusion}

Creatine kinase and creatine kinase fraction MB isoenzyme showed changes in their mean values in spite of treatment. These values remained higher than baseline for a longer time in animals treated with atropine-xylazine-ketamine $\mathrm{S}(+)$ or xylazine-ketamine $\mathrm{S}(+)$.

\section{References}

1. Borgbjerg FM, Frigast C. Segmental effects on motor function following different intrathecal receptor agonists and antagonists in rabbits. Acta Anaesthesiol Scand. 1997;41:586-94.

2. Errando CL, Sifre C, Moliner SY. Subarachnoid ketamine in swine-pathological findings after repeated doses: acute toxicity study. Reg Anesth Pain Med. 1999;24:146-52.

3. Lauretti, GR, Lima, IC, Buscatti, RY. Avaliação clínica, hemodinâmica, analgésica, psicodélica e anestésica de cetamina racêmica versus seu $\mathrm{S}(+)$ isômero. Rev Bras Anestesiol. 2000;13:357-62.

4. Raeder JC, Stenseth LB. Ketamine: a new look at an old drug. Curr Opin Anaesthesiol. 2000;13:463-8.

5. Cruz JM. Ketamina: una revisión de su mecanismo de acción y sus indicaciones en el caballo. Med Vet. 2003;20: 25-32.

6. Kolata RJ, Rawlings CA. Cardiopulmorary effects of intravenous xylazine, ketamine and atropine in the dog. Am J Vet Res. 1982;43:2196-8.

7. Haskins SC, Farver TM, Patz JD. Cardiovascular changes in dogs given diazepam and diazepam-ketamine. Am J Vet Res. 1986;47:795-8.

8. Luna SPL, Nogueira CS, Cruz ML, Massone F, Castro GB. Romifidine or xylazine combined with ketamine in dogs premedicated with methotrimeprazine. Braz J Vet Res Anim Sci. 2000;37:28-34.

9. Lemke KA. Perioperative use of selective alpha-2 agonists and antagonist in small animals. Can Vet J. 2004;45:475-80.

10. Boutureira, J, Trim CM. Acute pulmonary edema after diazepam-ketamine in a dog. Vet Anaesth Analg. 2007;34:371-6.

11. Marini RP, Li X, Harpster NK, Dangler C. Cardiovascular pathology possibly associated with ketamine/xylazine anesthesia in dutch belted rabbits. J Am Assoc Lab Anim Sci. 1999;40:153-60.

12. Xu Q, Ming Z, Dart AM, Du XJ. Optimizing dosage of Ketamine and Xylazine in murine echocardiography. Clin Exp Pharmacol Physiol. 2007;34:499-507.

13. Magoon KE, Hsu WH, Hembroung FB. The influence of atropine on the cardiopulmonary effects of a xylazine-ketamine combination in dogs. Arch Int Pharmacodyn Ther.1998;293:143-53.

14. Brock KA. Preanaesthetic use of atropine in small animals. Aust Vet J. 2001;79:24-5.

15. Parsons CG, Magnago TSI, Headley PM. At witch 'sigma' site are the spinal actions of ketamine mediated. Neurosci Lett. Amsterdan, 1998;85:322-8.

16. Linde-Sipman JS, Hellebrekers LJ, Lagerwey E. Myocardial damage in cats that died afther anaesthesia. Vet Quartely. 1992;15:91-4.

17. Berroëta $\mathrm{C}$, Provenchère S, Mongredien A, Lasocki S, Benessiano J, Dehoux M, Philip I. Dosage des isoformes cardiaques des troponines T ou I: intérêt en cardiologie et en anesthésie-reanimation. Ann Fr Anesth Reanim. 2006;25:1053-63.

18. Aktas M, Auguste D, Lefebvre HP, Toutain PL, Braun JP. Creatine kinase in the dog: a review. Vet Res Commun. 1993;17:353-69. 
19. Perez R, Garcia M, Cabezas I, Guzman R, Merino V, Valenzuela S, Gonzalez C. Actividad física y cambios cardiovasculares y bioquímicos del cavalla chileno a la competência de rodeo. Arq Bras Med Vet. 1997;29:221-34.

20. Kramer JW, Hoffmann WE. Clinical enzimology. In: Kaneko JJ, Harvey JW, Bruss ML. Clinical biochemistry of domestic animals. Publisher Academic Press; 1997. p.303-25.

21. Lopes STA, Franciscato C, Teixeira LV, Oliveira TGM, Garmatz BC, Veiga APM, Mazzanti A. Determinação da creatina quinase em cães. Rev Fac Zootec Vet Agro Urug. 2005;12:31-7.

22. Wyatt KM, Labuc R, Wyatt GL. Measurement of creatinine kinase MB in canine cardiac patients. Aust Vet J. 1998;76:826.

23. Diniz PPVP, Schwartz DS, Collicchio-Zuanaze RC. Cardiac trauma confirmed by cardiac markers in dogs: two case reports. Arq Bras Med Vet. 2006;59:85-9.

24. Kleber AG. ST-segment elevation in the electrocardiogram: a sign of myocardial ischemia. Cardiovasc Res. 2000;5:111-8.

25. Metha HB, Popovich BK, Dillman WH. Comparison of creatine kinase $\mathrm{M}$ and $\mathrm{B}$ subunit mRNAs and isoenzyme activity in ischemic dog myocardium. J Mol Cell Cardiol. 1987;19:882.
26. Scott SW, Murakami MM, Smith SA, Apple FS. Canine myocardial creatinine kinase isoenzymes after chronic coronary artery occlusion. Circulation. 1991;84.

27. Clark DM, Martin RA, Short CA. Cardiopulmonary responses to xylazine/ketamine anesthesia in the dog. J Am Anim Hosp Assoc. 1982;18:815-21.

28. Nunes N, Camacho, AA, Kronka, SN, Costa, JLO. Eletrocardiographic study of anesthetic combination of ketamine and chlorpromazine HCL in felines. Braz J Vet Res Anim Sci. 1996;33(2):313-6.

29. Tadich N. Valores bioquímicos sanguíneos de eqüinos que tiran carretones el La ciudad de Valdivia (Chile). Arch Med Vet. 2000;32:171-83. 30. Hjelms E, Hansen BF, Waldorff S, Steiness E. Evaluation of increased serum creatine kinase as an indicator of irreversible myocardial damage in dogs. Scand J Cardiovasc Surg. 1987;21:165-8.

31. Graeber GM, Wukich DK, Cafferty PJ, O'neill JF, Wolf RE, Ackerman NB, Harmon JW. Changes in peripheral serum creatine phosphokinase (CPK) and lactic dehydrogenase (LDH) in acute experimental colonic infarction. Ann Surg. 1981;194:708-15.

32. Yasuda J, Too K. Studies on serum creatine phosphokinase isoenzyme: seven cases of tetraplegia in the dog. Jpn J Vet Res. 1983;31:115-23.

\section{Correspondence:}

Leandro Guimarães Franco

Departamento de Medicina Veterinária - Setor de Cirurgia (UFG)

Estrada Saída Goiânia Nova Veneza, Campus II, Setor Samambaia

74630170 Goiânia-GO Brazil

Phone: (55 62) 3521-1572

lgvarjao@yahoo.com.br

Conflict of interest: none

Financial source: none

Received: August 18, 2008

Review: October 21, 2008

Accepted: November 19, 2008

\section{How to cite this article}

Franco LG, Fioravanti MCS, Damasceno AD, Borges AC, Soares LK, Rabelo RE, Silva LAF. Assessment of serum enzymatic markers of cardiomyocytes injury in female dogs submitted to ketamine $\mathrm{S}(+)$, atropin and xylazine association. Acta Cir Bras. [serial on the Internet] 2009 Jan-Feb;24(1). Available from URL: http://www.scielo.br/acb

*Color figures available from www.scielo.br/acb 